\title{
Judicial Analysis of Energy Management Regulation at Local Level After the Enactment of Act Number 23 Year 2014 on Local Government in Indonesia
}

\author{
Indah Dwi Qurbani \\ Chairman at the Center for Legal Studies on Oil, Gas, and Mining Law Faculty of Law \\ Lecturer at the Constitutional Law Department Faculty of Law \\ Brawijaya University \\ Malang, Indonesia \\ indah.qurbani80@ub.ac.id
}

\begin{abstract}
In the past, policies regulating energy have always considered that the abundance of energy resources must be utilized in an optimizing manner. Whereas energy is classified as a limited natural resource and economically valuable. Therefore, there is a need of certain awareness and care in exploiting it. In response to that, the problem in this research is: how is the juridical analysis of energy management in the region after the enactment of Act Number 23 Year 2014 on Regional Government. Based on the Act Number 23 Year 2014 on Regional Government, there are several sub-affairs authority such as in waste management, renewable energy and electricity which are the authority of the Central Government and the Provincial Government only. Under these circumstances, related acts and regulations must be adjusted to those provisions. The research method emloyed is normative juridical analysis.
\end{abstract}

Keywords----management, energy, regional.

\section{INTRODUCTION}

New and renewable energy is a major potential and asset in some areas that need to be developed as a part of support for the development of the region. Management and the use of new and renewable energy is aimed to increasing profit and welfare of the society with regard to sustainability. Therefore utilization of new and renewable energy should consider three main aspects: 1) to support regional development, 2) play a role in increasing the capacity of human resources as social capital, and 3) to develop and preserve the new and renewable energy as an asset and potential of the region.

As well as national conditions, all regions are dependent on fossil energy supply, so that such an interruption in the supply of fossil energy would hamper the ongoing development. In addition, the electrification ratio is not at $100 \%$ yet. As a result, in some villages there are still areas that don't have access to electricity. Several regencies in East Java province also have various potential energy as an alternative energy to fossil fuels in the future, such as: geothermal, hydroelectric, wave and ocean currents, wind power, solar power, biomass, biogas and energy from various plants (biofuels), but until now they have not been wellmanaged to make a significant contribution in the sector of energy supply. Therefore, the challenge ahead is how to actualize the condition of energy security in order to support sustainable regional development, a condition ensuring the availability of energy, people's access to energy at affordable prices in the long term and not affected by the situation of energy development at regional, national, and international level.

Management strategies and regional energy development is aiming to achieve the goals and objectives that have been established, namely that the energy sector can be selfsufficient in funding, efficient and transparent operation of the arrangements. National and local officials set energy policy based on energy balance of the planning process that has been compiled. Therefore, regions already have to think about the right strategy in energy management in their regional areas by considering the technical, legal and socioeconomic aspects.

Management and development of energy sector is also intended to provide and distribute energy to all households and villages as well as to meet energy needs in the economy. In general, industrial, commercial, and household sectors are growing rapidly. Energy Management Policy of the Local Government should describe the direction and goals related to price / tariff regional investment pattern applied to the region, the development and management of captive power in the industrial sector and policies related to the Demand Side Management (DSM), as well as energy development in rural areas or villages. Accordingly, the research on juridical analysis of energy management in the area after the enactment of Act No. 23 of 2014 concerning Local Government was conducted.

\section{DISCUSSION}

Decentralization adopted in the Indonesian Unitary State concept affects the relationship between the Central Government and Local Government. In connection with the distribution of authority over the regulation of government affairs. Article 1 Number 8 of the Act Number 23 of Year 2014 concerning Local Government states: "Decentralization 
means the transfer of government affairs by the central government to autonomous regions based on the principle of autonomy."

Principally, decentralization in Indonesia is in the form of decentralization of legislation (regeling) and government (bestuur). Regulated in Article 18 of the Constitution of the Republic of Indonesia Year 1945 (Constitution NRI 1945). The main purpose of decentralization is to free the central government from the unnecessary loads in handling domestic affairs, so they have the opportunity to learn, understand, and respond to various global trends and benefit caused. At the same time, the central government is expected to be able to concentrate on macro policy formulation, national strategic, and regions will undergo a significant process of empowerment. [1]

Article 33 paragraph (2) and (3) of the Constitution of 1945 affirms that the production branches which are important for the country and dominate the life of the people are controlled by the state. Similarly, earth, waters and natural resources contained therein are controlled by the state and used for the greatest prosperity of the people. State controls everything inside its territory and subsequently sets all the potential and interests through legal mechanisms accordingly. Therefore, the right to control by the state over land, waters and natural resources contained therein is essentially a protection and guarantees the realization of the overall prosperity of the people. The fourth paragraph of the preamble of the 1945 Constitution shows that Indonesia adheres to the concept of legal state material (welfare state) which is a concept of the state that provides power to the state to act actively and intervene (fries ermessen) in community activities to build community welfare. Consequently, the consequences may suppress the role of the public and put it under the State. [2]

Indonesia has eight (8) types of renewable energy sources which should be developed to meet national energy needs. Renewable energy is an energy source that is quickly restored back naturally, and the process is sustainable. Renewable energy is generated from energy resources that naturally will not be exhausted or it will even be sustainable if managed properly. Renewable energy is often referred to as energy (sustainable energy). Indonesia is a country with an abundance of renewable energy (renewable energy).

The concept of renewable energy began to be known by the world in the 1970s. It exists as an alternative to the problems of development and the use of fossil-based energy (coal, petroleum, and natural gas) and nuclear. Renewable energy is believed to be recovereable, cleaner (environmentally friendly), secure, and affordable for public. The use of renewable energy is more environmentally friendly because it can reduce environmental pollution and environmental damage in the appeal of non-renewable energy. Types of renewable energy sources (renewable energy) owned by Indonesia are pretty much. If those sources are utilized and managed properly, they are likely to replace fossil energy.

\section{LEGAL BASIS}

With regard to legal materials, there are eight (8) Acts regarded as a tool of analysis:

1. Constitution of the Republic of Indonesia Year 1945;

2. Act Number 26 Year 2007 on Spatial Planning (Official Gazette of the Republic of Indonesia Year 2007 Number 68, Supplement to State Gazette of the Republic of Indonesia Number 4725);

3. Act No. 30 of 2007 on Energy (Official Gazette of the Republic of Indonesia Year 2007 Number 96, Additional State Gazette No. 4746);

4. Act Number 12 Year 2011 on the Establishment of Legislation (Official Gazette of the Republic of Indonesia Year 2004 Number 53, Supplement to the State Gazette of the Republic of Indonesia Number 4389);

5. Act Number 21 Year 2014 regarding Geothermal (State Gazette of the Republic of Indonesia Year 2014 Number 217, Supplement to the State Gazette of the Republic of Indonesia Number 5585);

6. Act Number 23 Year 2014 regarding Regional Government (State Gazette of the Republic of Indonesia Year 2014 Number 244, Supplement to the State Gazette of the Republic of Indonesia Number 5587) as amended by Act No. 9 of 2015 on the Second Amendment to Act Number 23 Year 2014 regarding Regional Government (State Gazette of the Republic of Indonesia Year 2015 Number 58, Supplement to the State Gazette of the Republic of Indonesia Number 5679);

7. Presidential Regulation Number 1 Year 2014 on Guidelines for the General National Energy Plan;

8. Minister Regulation Number 80 Year 2015 concerning the Establishment of the Regional Legal Products (Official Gazette of the Republic of Indonesia Year 2015 No. 2036);

Article 18 paragraph (6) of the Constitution of the Republic of Indonesia Year 1945 [3];

The legal basis for the establishment of Regional Regulation is Article 18 paragraph (6) of the Constitution of the Republic of Indonesia Year 1945. The transfer of the majority of governmental authority to the local government, has put the local government at the forefront of national development in order to create prosperity for the people in a fair and equitable way. In this regard, the regional role and support to execute the development is seen quite essential, especially in terms of making regional regulations and other legal products in accordance with provisions of legislation.

Local Regulation as one of the national legislation has a constitutionalbasis and the juridical basis to the exclusion of the position of Regional Regulations in the 1945 Constitution. Article 18 paragraph (6) of the 1945 Constitution states that local governments have the right to set regional regulations and other regulations to implement regional autonomy and duty assistance. In this connection, the national legal systems provide attributive authority to the regions to establish Local Regulation (Perda) and other local regulations, and Perda is expected to synergistically support Government (National) programs in the regions. 
Local Regulations (Perda) as well as other legislation has the function to achieve legal certainty (rechtszekerheid). For the function of the legal certainty for the Regional Regulation must meet certain requirements, among others consistently in the formulation in which the same regional regulations should maintain systematic relationship between provisions, standard composition and language, and the harmonized relations between the various legis lations.

The harmonization of Regional Regulation (Perda) is important in relation to the principle of lower legislation which cannot interfere with the higher legislation; therefore, the fundamental thing in preparation of the Local Regulation draft is conformity with other legislation. Cancellation of a regulation implies that the harmonization of Central Regulation with Local Regulations does not go well.

Act Number 26 Year 2007 on Spatial Planning (Official Gazette of the Republic of Indonesia Year 2007 Number 68, Supplement to State Gazette of the Republic of Indonesia Number 4725) [4];

\section{Article 10}

(1) Authority of the provincial government in the implementation of spatial planning includes:

a. Regulation of, supervision of, and monitoring the implementation of spatial planning at provincial and region/city level, as well as the implementation of spatial strategic areas at provincial and region /city level;

b. Implementation of provincial spatial planning;

c. Implementation of the arrangement of the provincial strategic areas; and

d. Inter-provincial cooperation and facilitation of spatial arrangement of space cooperation between regions/cities.

(2) Authority of the provincial government in the implementation of the provincial spatial planning as referred to in paragraph (1) letter $b$ include:

a. Provincial spatial planning;

b. Provincial land utilization; and

c. Control of the use of provincial lands.

(3) In the arrangement of the provincial strategic areas as referred to in paragraph (1) letter $\mathrm{c}$, the provincial government implements:

a. The establishment of provincial strategic areas;

b. Spatial planning provincial strategic areas;

c. Utilization of the provincial strategic areas; and

d. Utilization of control of provincial strategic areas.

(4) The utilization of the space and utilization control of the provincial strategic areas referred to in paragraph (3) letter $\mathrm{c}$ and $\mathrm{d}$ could be performed by Local Government in region/city through Duty Assistance.

(5) In the framework of spatial planning of the province, the provincial government can draw up guidelines in spatial field at the provincial level and region/city level.

(6) In the exercise of powers referred to in paragraph (1), paragraph (2), paragraph (3), (4) and (5), the local provincial government:

a. Disseminates information relating to:

1) General plans and detailed spatial plan for the implementation of the provincial spatial planning;
2) The direction of zoning regulations for the provincial system is arranged in order to control the use of provincial land; and

3) Guidelines of spatial field;

b. implements minimum service standards for spatial field.

(7) In the case of the provincial government not being able to meet the minimum service standards for spatial field, the Government (national) take steps to accomplish in accordance with the provisions of the legislations.

\section{Article 11}

(1) The powers of local government districts / cities in the implementation of spatial planning include:

a. Regulation of, supervision of, and monitoring the implementation of the spatial arrangement of region/city and strategic areas of the region/city;

b. Implementation of spatial planning of region/city;

c. Implementation of the strategic areas of spatial region / city; and

d. Spatial planning cooperation between region/city.

(2) The powers of local government districts / cities in the implementation of spatial planning district / city referred to in paragraph (1) letter b include:

a. Spatial planning of region/city;

b. Spatial utilization of region/city; and

c. Spatial utilization of control of region/city.

(3) In the implementation of the spatial strategic areas of region/city as referred to in paragraph (1) letter c, Local Governments of Region/City to implements:

a. The establishment of strategic areas of the region/city;

b. Spatial strategic areas planning of the region/city;

c. Utilization of strategic areas of the region/city; and

d. Utilization of control of strategic areas of the region/city.

(4) In exercising the authority referred to in paragraph (1) and (2), the Local Government of region/city refers to the spatial field guidelines and instructions for implementation.

(5) In the exercise of powers referred to in paragraph (1), paragraph (2), (3) and (4), the Local Government of region/city:

a. disseminates information relating to the general plan and detailed plan for the implementation of the spatial arrangement of the region/city; and

b. implements minimum service standards for spatial field.

(6) In the case of local government region/city not being able to meet minimum service standards for spatial field, the Provincial Government can take steps for resolution in accordance with the provisions of the legislations.

The preamble of Act Number 26 Year 2007 on Spatial Planning states that the space of the Unitary Republic of Indonesia is an archipelago, which includes land space, sea space and air space, including space underground. It is necessary to improve management efforts wisely, efficiently, and effectively based on the rules of the space arrangement. Therefore, the quality of the national spatial planning could 
be sustainably maintained in order to actualize the common prosperity and social justice in accordance with the constitutional foundation of the 1945 Constitution of the Republic of Indonesia.

Space as a resource basically knows no boundaries. However, to create a safe, comfortable, productive, and sustainable national spaces based on the concept of Archipelago and National Security and in line with the actual regional autonomy policy that is comprehensive, and responsible for spatial planning, clear approach in the planning process is required in order to maintain harmony, balance, and cohesion between regions, national and locals, sectors, and among stakeholders. In this Act, spatial planning is based on a systematic approach, the main function of the area, adminis trative area, activity area, and the strategic value of the area.

In connection with the regional autonomy policy, the authority of spatial planning by the National Government and the Local Government, which includes the regulation, development, implementation, and oversight of the layout, is based on a regional approach to the administrative area boundaries. By the approach of the administrative areas, spatial planning throughout the territory of the Republic of Indonesia comprises national territories, provinces, regions, and areas of the city, each of which is a sub-systemof space according to administrative boundaries. The sub-system consists of human resources with a wide range of activities in utilization of natural resources and artificial resources, and with the level of different space utilization. Hence, if those activities are not maintained properly, it could bring unstable development in inter-regions and unsustainable use of spaces.

Act No. 30 of 2007 on Energy (Official Gazette of the Republic of Indonesia Year 2007 Number 96, Additional State Gazette No. 4746);

In the preamble of Act Number 30 Year 2007 on Energy, it is stated that energy resources are natural resources as mandated in Article 33 of the Constitution of the Republic of Indonesia Year 1945 controlled by the state and utilized for the common welfare of the people. The energy has very important role in terms of improvement of economic activities and national security. Therefore, the energy management, which includes the supply, utilization and enterprises, must be implemented in a fair, sustainable, optimized and integrated way. The reserves of non-renewable energy resources are limited. As a consequence, it is necessary to diversify energy resources in order to assure the energy availability [5].

In Article 18 paragraph (2) of Act Number 30 Year 2007 on Energy states that:

(1) The local government develops a general plan of regional energy with reference to the national energy plan as referred to in Article 17 paragraph (1).

(2) The general plan of regional energy as referred to paragraph (1) shall be determined by local regulations.

General Plan on Regional Energy (GPRE) is the Local Government policy on energy management plan at the local areas across sectors. The Formulation of General Plan on Regional Energy (GPRE) is urgent because that is the basis for the Local Government to create policies. As stated in Article 18 paragraph (1) and (2) of Act Number 30 Year 2007 on Energy, the Local Government formulates the General Plan on Regional Energy in accordance with General Plan of National Energy, and it is enacted through the regional regulation. GPRE will serve as a reference and guidelines for energy management at the local level across sectors, with the aim to meet the sustainable, fair, and optimized energy needs in order to achieve the local energy security and according to the objective of National Energy Management.

Act Number 21 Year 2014 concerning Geothermal Energy (State Gazette of the Republic of Indonesia Year 2014 Number 217, Supplement to the State Gazette of the Republic of Indonesia Number 5585);

The preamble of Act Number 21 Year 2014 concerning Geothermal states that geothermal energy is a renewable natural resource. The natural resources located in the territory of the Republic of Indonesia are gifts of God the Almighty whose interference is highly important to support national sustainable development in order to actualize the people's welfare. Geothermal is an environmentally friendly energy with huge potential but has not been optimally utilized; therefore, optimization should be encouraged, improved in the plan, and integrated in order to reduce reliance on fossil fuels. In order to maintain sustainability and national energy security as well as efficiency and effectiveness of the geothermal energy for indirect utilization for electricity, the government holds the authority to manage this field (National) [6].

The distribution of powers in the management of geothermal is presented as follows:

\section{Article 5:}

(1) The operation of the geothermal energy by the Government as referred to in Article 4 paragraph (2) shall apply to:

a. Geothermal for Direct Utilization located at:

1. The cross-province including production Forest Areas and Protected Forest Area;

2. Conservation Forest Area;

3. The conservation area in the waters; and

4. The sea area of more than twelve (12) miles from coastline to the open sea in Indonesia.

b. Geothermal for Utilization Indirect located in all regions of Indonesia, including production forest area, protected forest area, forest area conservation, and marine areas.

(2) The Geothermal by the provincial government as referred to in Article 4 paragraph (2) shall be conducted for Direct Utilization located:

a. across districts / cities in the province including production forest area and forest lands protected; and

b. in most remote ocean regions twelve (12) miles from the coastline to the open sea and / or in the direction of the archipelagic waters.

(3) Operation of Geothermal by the district / city referred to in Article 4 paragraph (2) shall be conducted for Direct Utilization located in:

a. districts / cities including production forest area and forest lands protected; and 
b. most remote ocean areas $1 / 3$ (one thirds) of marine areas of provincial jurisdiction.

Article 6

(1) The authority of the Government in the implementation of the Geothermal referred to in Article 5 (1) includes:

a. national policy-making;

b. setting in the field of Geothermal;

c. Geothermal permit grant;

d. Direct utilization permit grant of an area under the government's authority;

e. guidance and supervision;

f. data management and geological information as well as potential Geothermal;

g. inventory and preparation of balance sheet resources and Geothermal reserves;

h. the geothermal exploration, exploitation, and / or utilization; and

i. the encouragement of research, development and engineering capabilities.

(2) The authority of the Government in the geothermal implementation as referred to in paragraph (1) shall be implemented and / or coordinated by the Ministry.

\section{Article 7}

The authority of the provincial government in the implementation of the Geothermal as referred to in Article 5 (2) includes:

a. The establishment of local legislation in the field of geothermal provinces for Direct Utilization;

b. Direct utilization permit grant of an area under the government's authority;

c. Guidance and supervision;

d. Data management and geological information as well as potential Geothermal in provincial areas; and

e. Inventory and preparation of balance sheet resources and geothermal reserves in the province.

\section{Article 8}

The authority of district / city governments in the geothermal implementation as referred to in Article 5 (3) includes:

a. The formation of legislation districts / cities in the geothermal field for direct utilization;

b. Direct utilization permit grant of an area under the government's authority;

c. Guidance and supervision;

d. Data management and geological information as well as potential Geothermal at regions/cities; and

e. Inventory and preparation of balance sheet resources and geothermal reserves at regions /cities.

Act Number 12 Year 2011 concerning the Establishment of Legislation [7]

\section{Article 14}

The substance of Provincial Regulation and Region/City Regulation consists of the substance in the framework of regional autonomy and duty of assistance and to accommodate the particular conditions of the area and/or the further elaboration of higher legis lation
Based on constitution and the concept of local autonomy, Local Governments have the powers to create local regulations as one of the authorities in the field of legislation. The objective of this local autonomy is to accelerate the realization of public welfare by improving services, empowerment, and community participation, improving the competitiveness of the region, by taking into account the principles of democracy, equality, justice, privilege, and the specificity of a region.

In addition, Act Number 12 Year 2011 also provides guidance on the establishment of a fairly detailed legislation, especially to local regulations, from the stage of preparing academic papers to enactment.

Act Number 23 Year 2014 concerning Regional Government (State Gazette of the Republic of Indonesia Year 2014 Number 244, Supplement to the State Gazette of the Republic of Indonesia Number 5587) as amended by Act Number 9 Year 2015 on the Second Amendment to Act Number 23 Year 2014 concerning Regional Government (State Gazette of the Republic of Indonesia Year 2015 Number 58, Supplement to the State Gazette of the Republic of Indonesia Number 5679) [8];

Article 236

(1) To organize regional autonomy and coadministration task, Regional Regulation is made.

(2) Local Regulation, as referred to in paragraph (1), is created by Regional House of Representatives (DPRD) with the mutual consent of Regional Heads.

(3) Local Regulation, as referred to paragraph (1), shall contain the following substance:

a. Regional Autonomy and Duty Assistance; and

b. Further elaboration of the provisions of the higher legis lation.

(4) In addition to the substance as referred to in paragraph (3) the Local Regulation could load local content material in accordance with the provisions of the legis lation.

\section{Article 237}

(1) The principle of the formation and the substance of legislation are based on the provisions of legislation and legal principles that grow and thrive in society as long as not contrary to the principle of the Unitary Republic of Indonesia.

(2) The formation of Local Regulation (Perda) consists of planning, drafting, discussion, establishment and enactment guided by the provisions of the legis lation.

(3) Society has the right to provide verbal input and/or written in the formation of legislation.

(4) Formation of Local Regulation (Perda) as referred to in paragraph (2) is conducted effectively and efficiently.

Article 238

(1) Local Regulation (Perda) may include provisions about charging of coercion enforcement / implementation of the Regulation wholly or in part to the offender in accordance with the provisions of the legislation. 
(2) Regulation may contain the threat of imprisonment for maximum of 6 (six) months or a fine of $\mathrm{Rp}$. 50,000,000.00 (fifty million rupiah).

(3) Regulation may impose imprisonment or criminal penalties other than those referred to in paragraph (2) in accordance with the provisions of the legislation.

Act Number 23 Year 2014 Addendum concerning Local Government in regard to 3 (three) sub affairs :

Act Number 23 Year 2014 Addendum concerning Local Government states that the authorities of the Central Government in regard to sub waste section includes:

a. Issuance of permits regarding incenator for management of waste transformed to electrical energy.

b. Issuance of permits regarding utilization of methane for electrical energy in landfill by the regional private sectors.

The Provincial Government and Regional/City Government do not have the authority.

For the sub-affair of renewable energy based on Act No. 23 of 2014 Addendum concerning Local Government, it is stated that the authority of the Central Government is as follows:

a. Establishment of geothermal working areas.

b. Auction of geothermal working areas.

c. Is suance of permits regarding direct use of geothermal energy in the Regions across provinces.

d. Issuance of permits for the indirect geothermal utilization of geothermal.

e. Establishment of electricity and / or geothermal steam.

f. Establishment of business entities authorised to manage water power to generate electrical power.

g. Issuance of registration certificate of supplementary services-based business operating across provinces.

h. Issuance of permits for commercial businesses of biofuels as another fuel with a capacity of supplying over 10,000 (ten thousand) tons per year.

While the provincial government authority in the subaffair of renewable energy involves:

a. Is suance of permits regarding direct use of geothermal energy across regions/cities in one (1) provincial area.

b. Issuance of registration certificate of supplementary services-based businesses operating in one (1) provincial area.

c. Is suance of permits, as sistance and supervision of the commercial business of biofuels (biofuels) as another fuel with the supply capacity of up to 10,000 (ten thousand) tons per year.

For the Government of Region/City's authority in subaffair of renewable energi is: Is suance of permits for direct use of geothermal energy by Regions/Cities.

For sub-affair of electricity, the Central Government's Authority comprises:

a. Establishment of business region for providing electrical power and permit of cross country electricity trade

b. The issuance of business license for electricity supply in cross province, state-owned enterprises and the sale of electricity and network leasing for electrical providers cross province or state-owned enterprises.

c. The is suance of operating licenses that the installation facilities include Regional inter-provincial or located in the area beyond 12 nautical miles.

d. Establishment of electricity tariffs for consumers and issuance of permits for the utilization of telecommunications, multimedia, and information from the license holder issued by the Central Government.

e. Approval of selling price of electricity and electrical power network leasing, power supply business plans, sales of excessive electricity from the license holder issued by the Central Government.

f. The issuance of electricity supporting business services that are carried out by state-owned enterprises or foreign investors / shares majorly owned by foreign investors.

g. Provision of funds for the underprivileged groups, the construction of undeveloped electric supply facilities, remote and rural areas.

Authority of the Provincial Government in the sub-affair of electricity are as follows:

a. The is suance of electricity supply business license non state-owned enterprises and the sale of electricity and network leasing provider for electrical power in the provincial regions.

b. The issuance of operating licenses for installation facilities in the province Regions.

c. Establishment of tariff imposed on electricity for consumers and the issuance of permits for the utilization of the telecommunication, multimedia, and information from the license holder issued by the regional government of the province.

d. Approval of the sale price of electricity and the rental of electric power network, electricity supply business plans, sales of excessive electricity from holders of license is sued by provincial government.

e. The is suance of supporting electricity-related service business licenses for business entities in the country / in which the shares are majorly owned by domestic investors.

f. Provision of funds for the underprivileged groups, the construction of undeveloped power supply facilities, remote and rural areas.

In connection to the electrical sub-affair of Region/City Government does not have the authority.

\section{ANALYSIS}

In carrying out affairs under the authority of Local Government, regional heads and Regional House of Representatives (DPRD) as the Regional Government actors shall create the Local Regulation (Perda) as the legal basis for organizing the Local Autonomy in accordance with the conditions, aspirations and the uniquenes s of the locals. Local Regulation made is only valid within the limits of the jurisdiction of the relevant locals. Nevertheless, Local Regulations Issued by the Local Government shall not conflict with the provisions of higher legislation in accordance with the hierarchy of legislation. Besides, Local 
Regulation as part of a legislation system and regulations shall not conflict with the public interest as stipulated in the rules of legislation-making process. It is also applied for the energy management in the Local that shall be in accordance with the powers as regulated in the Addendum of Act Number 23 Year 2014 concerning Local Government.

\section{Presidential Regulation Number 1 Year 2014 concerning Guidelines for the Formulation of General Plan of National Energy ${ }^{1}$ [9] \\ Article 16}

(1) Provincial Government drafts the formulation of RUED-P ${ }^{2}$ with reference to RUEN.

(2) The drafting of RUED-P as referred to in paragraph (1) is conducted by the Unit of Work in Provincial Government who held government affairs in the energy field to include:

a. Government;

b. Governemnt of Region/City; and

c. Stakeholders

(3) The draft RUED-P as referred to in paragraph (1) shall at least contain:

a. The current and future energy situation;

b. The establishment of vision, mission, goals, and objectives of local energy in the form of the target and the target to be achieved; and

c. policy and local strategy in energy management in accordance with the policies, strategies, institutional, policy instruments, and energy development programs.

(4) The drafting RUED-P implemented in accordance with to the systems as listed in the Addendum which is an integral part of the Presidential Regulation.

(5) RUED-P is set out by Provincial Regulation.

\section{Article 7}

(1) RUED-P shall be established at least one (1) year after RUEN is established.

(2) RUED-P could be reviewed and updated every 5 (five) years, or any time in accordance with changes in the environment strategy and / or changes of RUEN.

\section{Article 8}

(1) The government of region/city drafts the formulation of region / city's RUED by referring to RUEN and RUED-P.

(2) The drafting of RUED-Region / City is referred to in paragraph (1) shall be implemented by the Work Unit of Region / City that held the government affairs in the energy field to engage:

a. provincial government; and

b. stakeholders.

(3) The drafting of RUED-Region / City referred to in paragraph (1) shall at least contain:

a. The current and future energy situation;

b. The establishment of the vision, mission, goals, and objectives of regional energy in the form of the target and the target to be achieved; and

c. Policy and regional energy management strategy shall be in accordance with the policies, strategies, institutional, policy instruments, and energy development programs.

(4) The drafting of RUED-Region / City carried out in accordance with the systems as listed in Addendum which is an integral part of this Presidential Regulation.

(5) RUED-Region / City is defined by Local Regulation of a Region/ City.

\section{Artile 19}

(1) RUED-Region/ City is established at least 1 (one) year after RUED-P is established.

(2) RUED-Region / City could be reviewed and updated every 5 (five) years or at any time in accordance with changes in the environment strategy and / or changes of RUEN.

Based on Act Number 23 Year 2014 concerning Local Government, there are some authorities in the sub section of waste management, renewable energy and electricity that are under the authorities of Regional Government and Provincial Government, as elaborated in in the evaluation and analysis of the Act Number 23 Year 2014 concerning Former Regional Government. This condition requires related Act to adjust.

Minister Regulation Number 80 Year 2015 concerning the Establishment of the Local Legal Products (Official Gazette of the Republic of Indonesia Year 2015 No. 2036);

The regulation is related to the establishment of the Local Legal Products, which also regulates establishment mechanism of Provincial Regulation and Region / City's Regulation [10].

\section{POTENTIAL OF ENERGY MANAGEMENT IN THE LOCAL}

Energy use covers almost all aspects of community's life. Human life can not be separated from energy. Due to the essence of energy and its exploration and use, controversy and debates often emerge at policy level. Hence, it is necessary to use energy as well and efficiently as possible.

Energy policy in the past considered that energy resources were so abundant that its use must be optimized. Whereas energy is a finite natural resources and economically valuable, it is necessary to be aware of the utilization.

The progress of Article 21 paragraph (1) of Act Number 30 Year 2007 on Energy mandates that energy utilization is carried out to optimize the full potential of energy resources, to consider aspects of technological, social, economic, conservation and the environment, and to prioritize community needs and increase economic activity in the area of energy source.

In fact, in terms of the implementation, these three as pects are ignored [11]. On the issue of energy it could not be separated from mining problems, especially oil and gas. Indonesia's oil reserves are just 4.8 billion barrels and the use each year accounts for about 200 million barrels; therefore, 
Indonesian people could only enjoy approximately 10 (ten) years. It is very important to create alternative energy sources other than oil and gas, supported by the energy policy model based on public interests.

New and renewable energy as an asset and a major potential in some areas need to be developed in order to support the development of the area. Management and the use of new and renewable energy are aimed to increase the incomes and welfare with due regard to sustainability. Therefore, the utilization of new and renewable energy should consider three main aspects: 1) to support regional development, 2) to play a role in increasing the capacity of human resources as social capital, and 3) to develop and preserve the new and renewable energy as an asset and local potential.

Management strategies and regional energy development are aimed to achieve the goals and objectives that have been established, that the energy sector can be self-sufficient in funding, efficient in the operation, and transparent in the regulation. Central and local officials establish the energy policy that is based on the energy balance planning process that has been compiled. Therefore, the local shall start to think about the right strategy in the energy management of the locals by taking into account the technical, legal and socio-economic aspects.

Management and development of energy sector is also intended to provide and distribute energy to all households and villages as well as to meet energy needs in the economy such as industry and commercial sectors, which are growing rapidly, and the household sector. Local Government Management of Energy Policy shall describe the objectives and goals related to regional price / tariff, investment pattem applied in local areas, the development and management of captive power in the industrial sector and policies related to the Demand Side Management (DSM), as well as energy development in rural areas (villages). Management, assistance and development of energy resources are included in a multidisciplinary process that is comprehensive and based on the principle and planning process that take into account the technical as pects as well as non-technical as pects in terms of exploitation which includes legal, social and economic / financial as pects. The utilization program of new and renewable energy sources typically utilize the energy potential in the local site and is mostly geared to meet the needs of the community and local industry / local area whereas energy needs are generally intended for cooking and lighting. Most of the customers are domestic and industrial community local. The electrical energy is still largely used by the community for lights and daily consumption (watching television, radio, VCD) and only as small amount of customers who use the energy for productive business that could run the family economy (economic generating)

Local Energy Management on the technical aspects of the supply and energy consumption with the principle of lowest cost covers the needs for energy facilities and infrastructures, lowest cost alternative and planning horizon (short, medium and long). In addition, the process of planning and management system of energy (petrol / gas fuel and non-fuel / CNG) includes: planning of energy needs by sector, planning the development of the generation of potential energy resource, reserve level / degree of reliability, availability's illustration of primary energy sources including renewable energy, the utilization of local energy and priority selection, planning on the energy supply, planning on the development of the distribution system, load forecasting and distribution planning.

Local Energy Management on the legal aspect is the local energy management that takes into account the national energy policy development regulation, regulation of local energy development policies both from Central Government and other locals related to energy development in the local. While the aspects of the energy management on the social economic / finance is the local energy management that takes into account the socio-economic conditions of society, the pros pects for the development of renewable energy in support of socio-economic development of society as well as the study of civil society organizations are related to the development and implementation of new renewable energy community.

The potential of biomass in Indonesia that could be used as an energy source is very abundant. Was te derived from animals and plants are potential to be developed. Food crops and plantation produce enough waste, which can be used for other purposes such as biofuels. Utilization of waste as biofuel provides three immediate benefits.

1. The increase of overall energy efficiency due to huge energy content in the waste.

2. Cost saving due to the fact that waste dis posal can be more expensive than the utilization

3. Reducing the need for landfill because the use of landfill will be more difficult and expensive, particularly in urban areas.

In addition to the utilization of waste, biomass as primary products for energy resources has also developed rapidly lately. Palm, castor, soybean are several types of plants in which the products are mainly used as a primary material for making biodiesel. Meanwhile, cassava, maize, sorghum, and sago are plants often intended as materials for bioethanol.

Indonesia as a tropical agricultural country has a huge renewable energy resource potential. The potential of biomass energy sources has reached $49.81 \mathrm{GW}$, but the new installed capacity is $302.4 \mathrm{MW}$. If this potential is maximized by the increasing amount of installed capacity, it will help the diversification of energy as fossil fuel which has become the foundation of energy use. Hence, it will help the economy that has been ruined due to excessive fuel oil subsidy budget over the budget of different sectors.

Biomass energy becomes important when compared to other renewable energy, because the process of conversion into electrical energy has cheaper investment. This is the excessive biomas s compared to other energy. Biomass energy process itself utilizes solar energy to convert $\mathrm{CO} 2$ and water into carbohydrates through photosynthesis.

Indonesia as an agrarian country that still has farms and large plantations would not be difficult to get a waste from agriculture and plantation. In terms of waste from plantations, oil palm is considered to have its own market sectors and in the utilization of waste. However, rice, corn, coconut, sugarcane and sawn timber are still lacking in terms of the 
utilization. For instance, remaining burning paddy husk in every harvest's post shows that the waste of paddy is still underutilized. To make the natural resources beneficial in the long time, it should take wisdom in the use of natural resources in order to be sustained by utilizing waste biomass into a renewable energy source.

\section{CONCLUSION}

1. Energy management at the local as outlined in the Local Regulations where materials and the substance are contained in it shall conform with the authority of the Central Government, Provincial Government and Region / City Government as set out in the Addendum to Act Number 23 Year 2014 on Local Goverment.

2. New and renewable energy as an asset and a major potential of the Local need to be developed in order to support the development of the Local. Management and the use of new and renewable energy are aimed to increase the incomes and welfare with due regard to sustainability. Therefore, the utilization of new and renewable energy should consider three main aspects: 1) to support regional development, 2) to play a role in increasing the capacity of human resources as social capital, and 3) to develop and preserve the new and renewable energy as an as set and local potential.

\section{REFERENCES}

[1] D. Setiawan, Autonomous Region in Perspective Environmental and Resource Values, Jakarta: Djambatan, 2004.

[2] M. M. MD, Democracy and Constitution in Indonesia, Jakarta: Risneka Cipta , 2000.

[3] Constitution of the Republic of Indonesia Year 1945.

[4] Act Number 26 Year 2007 on Spatial Planning (Official Gazette of the Republic of Indonesia Year 2007 Number 68, Supplement to State Gazette of the Republic of Indonesia Number 4725).

[5] Act No. 30 of 2007 on Energy (Official Gazette of the Republic of Indonesia Year 2007 Number 96, Additional State Gazette No. 4746).

[6] Act Number 21 Year 2014 on Geothermal (State Gazette of the Republic of Indonesia Year 2014 Number 217, Supplement to the State Gazette of the Republic of Indonesia Number 5585).

[7] S. t. t. S. G. o. t. R. o. I. N. 4. Act Number 12 Year 2011 on the Establishment of Legislation (Official Gazette of the Republic of Indonesia Year 2004 Number 53.

[8] Act Number 23 Year 2014 regarding Regional Government (State Gazette of the Republic of Indonesia Year 2014 Number 244, Supplement to the State Gazette of the Republic of Indonesia Number 5587) as amended by Act No. 9 of 2015 on the Second Amendment to Ac.

[9] Presidential Regulation No. 1 Year 2014 on Guidelines for the General National Energy Plan.

[10] Minister Regulation No. 80 Year 2015 concerning the Est ablishment of the Regional Legal Products (Official Gazette of the Republic of Indonesia Year 2015 No. 2036).

[11] E. Bulletin, Trying New Steps: Utilizing Alternative Energy, Environmental Forum (WALHI), East Java, Civil Society Support and Strengthening Program, Issue 2/2001, 2001.

[12] Act Number 26 Year 2007 on Spatial Planning (Official Gazette of the Republic of Indonesia Year 2007 Number 68, Supplement to State Gazette of the Republic of Indonesia Number 4725). 